\title{
Capital assets and intercultural borderlands: socio-cultural challenges for natural resource management
}

\author{
Elaine Stratford* and Julie Davidson
}

\author{
Principles Researchers, Sustainable Communities Research Group, School of Geography and \\ Environmental Studies, University of Tasmania, GPO Box 252-78, Hobart TAS 7001
}

Received 31 July 2000; accepted 31 May 2002

\begin{abstract}
In their design or implementation, many natural resource management (NRM) programs ignore critical socio-cultural dimensions of the challenge to advance sustainability. Building on particular ideas about culture and human ecosystems, we combine the strengths of the capital assets model of sustainability and the idea of intercultural borderlands to respond to this gap. To advance our thesis about the utility of these tools, we critically reviewed and analysed a cross-disciplinary literature relating to the socio-cultural dimensions of NRM. This paper stems from that labour and examines particular tensions that arise in land management as a result of Australians' specific colonial and postcolonial legacies. These tensions - related to ethnicity, gender, population, age and health - are among the threads in the larger tapestry that comprises the socio-cultural dimensions of NRM. For the Australian case, they are central, longstanding and persistent, and thus worthy of analysis; and they are applicable in general terms to other places with similar histories of settlement and land use.
\end{abstract}

(C) 2002 Elsevier Science Ltd. All rights reserved.

Keywords: natural resource management, the socio-cultural, capital assets, intercultural borderlands, sustainability, Australia.

\section{Introduction}

There is a problem with natural resource management - an insufficient appreciation of everyday values, attitudes and social practices, social norms and cultural dispositions, and how these frame responses to the challenges of sustainability. In particular, NRM's reductive methods, while useful to scientific practice, do not sufficiently account for the diverse methods by which people create, maintain and change their identities, values and actions. Accounting for the interdependencies between NRM, scientific research and socio-cultural practices means generating complex solutions to the

\footnotetext{
*Corresponding author. Tel: +61 36226 2462; Fax: 62262989 ;
} Email: Sust.comm@utas.edu.au dilemmas of unsustainable resource use (Beever, 1993; Dovers and Mobbs, 1999).

NRM is about managing people's activities as much as it is about managing resources (Brown, 1997). Accordingly, 'the natural resource professions will need to intensify their search for models of resource systems that include the forces driving infinite human desires...' (Machlis et al., 1997, 348). In the meantime, a significant implementation deficit exists in NRM strategies and practices. Recognizing this state of affairs, in 1999 Land and Water Australia ${ }^{1}$ (LAWA) developed the Social and

\footnotetext{
${ }^{1}$ Land and Water Australia (formerly the Land and Water Resources Research and Development Corporation) is a federally funded R\&D organization. We acknowledge its support in funding this research, and note that any deficiencies in this paper are ours alone.
} 
Institutional Research Program (SIRP) to address these matters. The Program builds 'awareness of all factors which drive or impede improved natural resource management, and [provides] options for enhancing the drivers and overcoming the impediments' (LWRRDC, 2000, 3). It incorporates numerous projects among which was one to initiate the development of a knowledge base on the social and institutional dimensions of NRM.

This paper is drawn from a research consultancy undertaken by the authors to begin that task for LAWA. In it, we focus on the socio-cultural dimensions of NRM in Australia to underscore our primary claim that concerted efforts need to be made by policy-makers and practitioners to better understand the complexities of the socio-cultural in order to raise the effectiveness, equity and efficiency of NRM strategies (Perreault et al., 1998); and improve the delivery of information and programs for sustainable NRM.

\section{Conceptual framework}

Before examining the details of our case, we outline the conceptual framework that underpins our work. That task requires an openness about how we deploy the term 'socio-cultural', and for that we are indebted to the work of others. First, of culture, Geisler $(1999,51)$ observes that:

Over the last century, culture has come to mean a people's cumulative way of life, both material and nonmaterial. It comprises morals, art, custom, language, religion, law, and other institutions, including property rights. Thus culture bounds the land in diverse ways and makes place out of space. Culture marks the corners and edges of place; it selects which places will be sacred and which will be sacrificed; it yields maps of place and bestows place names; it defines tenure and imbues ownership types with social distinction; and it decides the aesthetics and ethics of the land.

Second, a detailed delineation of the interrelationships among the social and the cultural is furnished by Machlis et al. (1997). Where Geisler writes of culture, Machlis and his colleagues use the term 'human social system' to mean social institutions (health, justice, faith, commerce, education, leisure, government, and sustenance); social cycles (physiological, individual, institutional and environmental); and social order (identity, norms and hierarchy). Where Geisler emphasizes space and place, they write about critical natural resources (energy, land, flora and fauna, water, materials and nutrients), socio-economic resources (information, population, labour and capital) and cultural resources (organization, beliefs and myth). They also stress the importance of flows between these and the social system that, together, constitute the human ecosystem. To understand the complexities of culture and human ecosystems is to forge novel interdisciplinary relationships.

Currently, the interrelationships among natural, economic and cultural resources are not well recognized because of the pre-dominance of economic capital over other assets. Natural resources are valued largely as inputs and consequently their non-economic values and the potential of these values as capital assets are accorded minimal consideration. In this context, Farina (2000, 313) argues that, because two-thirds of the planet's land surfaces have been modified by human activities and are therefore cultural landscapes, they 'represent a fundamental storehouse of the earth's natural and cultural capital'. His case is that cultural capital once informed and maintained the relationship between economic activities and natural resource use, but that it no longer has that mediating role because economic capital is overprivileged and natural capital used up and degraded. At the same time, much of the human and social capital that would activate cultural resources lacks for enhancement or is in decline (Pretty and Hine, 2000). To prevent economic assets being accumulated at the expense of natural assets, Farina (2000) proposes reactivating 'cultural switches'. In this paper we endeavour to discern some of those switches-better attention to difference, locality, particularity - for sustainable NRM by investigating certain intercultural borderlands - an idea we derive from Sandercock (1998). We also employ an integrated capital assets approach (Pretty and Frank, 2000) to sustainability to better understand how human, social, physical and financial assets might be more beneficially deployed for the accumulation of natural assets. Our work is both synthetic and constitutive of new ideas.

The economy-ecology-society model of sustainability has authority in NRM, but is an overly simplified schematic which does not acknowledge the embeddedness of economy in society, society in environment (Hart, 2002). We prefer a capital assets-based approach to sustainability because it affords a more nuanced understanding of these interdependencies. The utility of the capital assets model resides firstly in its transcendence of 'the arcane division of the biophysical from the 
socio-cultural' (Machlis et al., 1997, 348) allowing an improved appreciation of the contribution that all capital assets ${ }^{2}$ - natural, social, human, physical and financial - make to well-being not just economic assets; and secondly, in its basic understanding that sustainable systems accumulate stocks of assets while unsustainable systems deplete these stocks (Pretty, 2000; Pretty and Ward, 2001). Consequently, this model shifts the focus of productive activity from inputs to assets such that land and ecosystem processes, social processes, or individual skills come to be viewed not as resources to be used up but as assets to be maintained and renewed, indeed accumulated.

Because it accounts for the human ecosystem idea and emphasises the importance of social and cultural dimensions of sustainability, after Machlis et al. (1997) and Geisler (1999), the capital assets model that we propose aids the development and implementation of integrated policy that enhances NRM and other outcomes. For example, surveys about sustainability and community undertaken over three years by the authors and others throughout the Huon Valley Municipality, south of Hobart, the capital of Tasmania, demonstrate a number of challenges related to sustainability. In particular, economic reliance on export-oriented primary industries has directly affected the educational opportunities for the community's youth, with the result that the quality of human capital has been compromised. Furthermore, prospects for the community's sustainable development may be retarded without other interventions (Davidson, forthcoming). One such intervention is the integration of capital assets via catchment management (Huon Valley Council, 1999). ${ }^{3}$ In integrated catchment management, capital assets are treated as interdependent. This interdependence is illustrated in the Huon Healthy Rivers Project, a nationally recognized integrated catchment management strategy funded by Federal, State and local government funds, based on NRM and successfully implemented via a series of alliances and networks among community members, scientists, industry and land managers with very different priorities (Dietzel,

\footnotetext{
${ }^{2}$ Natural Capital is nature's goods and services. Social Capital is the cohesiveness of people in their societies. Human Capital is the status of individuals' potential, health and well-being. Physical Capital is the store of human-made material resources. Financial Capital is financial systems including credit, grants, welfare payments and investments (Pretty and Frank, 2000, 179).

${ }^{3}$ Significantly, Council is currently debating the merits of using a capital assets framework in its next Strategic Plan, informed by extensive work undertaken by the authors to show the model's analytic and integrative utility (Stratford and Davidson, 2001).
}

1997). This Program has had net benefits for natural, physical, social, human and financial capital assets by improving water quality, enhancing the better use of Council infrastructure such as weirs, building trust, developing ecological literacy and civic skills among participants, and saving money in mitigating environmental degradation (Stratford and Davidson, 2001).

As a rational model, the capital assets approach thus draws attention to the existence of interdependencies between the various stocks of assets. Notwithstanding this utility, an additional approach is needed to value such interconnections affectively, re-establishing the importance of cultural capital as that which maintains the relationship between economic and natural capitals. Here, then, we turn to the idea of the intercultural borderlands - which are simultaneously conceptual and material spaces between different people and groups; tools by which to work through cultural differences and recognize the interrelationships among different forms of identification; and an emancipatory strategy by which to move beyond adversarial politics.

Paying attention to intercultural borderlands may have certain positive effects on NRM: more and potentially improved information on which to base decisions and policy; prospects for improved adaptive capacities in relation to changing environmental parameters; and possibly a greater ability to address major and complex land and water degradation issues. Beyond these matters, however, we justify this focus on the socio-cultural because we see little evidence that such knowledge is informing policy development for NRM in Australia. Indeed, in policy forums we have witnessed senior policy makers explicitly undervaluing socio-cultural dimensions of NRM as 'soft' or 'unscientific', observations which reflect differential power relations in the production of knowledge, and privilege particular ways of knowing over others (Clark, 1993; Labinger, 1995; Machlis et al., 1997; Stratford et al., 2000). Yet it is in the intercultural borderlands that the potential exists for creative and compassionate modes of NRM, approaches mindful of equity and effectiveness as well as efficiency.

In order to advance our thesis, in our work for Land and Water Australia we critically reviewed ${ }^{4}$ and analysed a range of socio-cultural issues in light of insights provided by the capital assets model and

\footnotetext{
${ }^{4}$ This review draws on an extensive database of the literature on the social and institutional dimensions of NRM constructed in the course of our work for Land and Water Australia noted above.
} 
the idea of intercultural borderlands as emancipatory politics. Our reporting of that review in this paper is organized as follows. Acknowledging the prior custodial claims of Australian Aboriginal peoples, we begin by fleshing out some of the tensions that arise in land management from our collective colonial and postcolonial legacy. Building on that ground, we elaborate on the challenges to NRM posed by Australia's diverse ethnic composition. We then discuss the various problems that arise for better NRM as a result of the complex intersections among gender, generations and health because these are three intercultural borderlands that we can demonstrate as deeply affecting NRM, but that are not often acknowledged as having such influence. We concede that these mattersindigeneity, ethnicity, gender, population, age and health-are threads in the larger tapestry of the socio-cultural dimensions of NRM but, for the Australian case, they are central, longstanding and persistent. In conclusion we sketch out what we think are the major lessons to be drawn from this review and analysis.

\section{Cultural dispositions, colonial myths, postcolonial strategies}

Cultural disposition is always spatial. However, there is a fine line between suggesting that people are influenced by place, and proposing that these places determine who we are (Stratford, 1999). Assuredly, however, European possession of Australia has produced paradoxical and messily juxtaposed mythologies about spaces, places and identities. Among these are the manliness of exploration and conquest, the outback and bush, the corrupt and cosmopolitan city, the empty interior, the cool coast, the beach babe, the football hero, the local pub, quiet country towns, wilderness (Fiske et al., 1987; Schaffer, 1988; Drew, 1994).

Take the first of these mythologies; the penetration of the continent by Europeans. Although, as Rose $(1996,18)$ stresses, there is no place 'where the country was not once fashioned and kept productive by Aboriginal people's land management practices', the impulse to 'civilize, Christianize and colonize' is writ large across the Australian landscape and has been well documented (Powell, 1978; Hills, 1991; Mitchell, 1994; Ryan, 1996; Stratford, 2000). For Australia to be developed, the dispossession of the Aborigines and the alienation of land into private ownership were critical. Three methods to obtain sovereignty over land were recognized during Australia's white settlement: conquest, cession; and occupation of land that was 'unoccupied' or peopled by 'backward' inhabitants. Obtained in such manner, the acquisition of land was seen as valid and just occupation or settlement for the purposes of 'improvement' (Butt and Eagleson, 1998; Davidson, 1999). On the one hand, these acts necessitate what Riddett (1995) refers to as the construction of 'social memory' in which all that is good about being Australian has involved a denigration of everything that was here before settlement. On the other hand, these transformations require the denial of the 'Aboriginal-Other' via mechanisms such as terra nullius which means 'land of no-one', and which has deeply divided the nation over land rights and human rights (see Baker, 1999, for example).

Philosophically, politically and practically, reconciliation between Aboriginal and non-Aboriginal Australians is critical, not least (for our purposes here) because to deny indigenous land claims is often also to deny Aboriginal land management practices. Therefore, it is constructive to recognize efforts among indigenous and non-indigenous people to forge common ground in NRM. Certainly, co-management affords opportunities for what Notzke $(1995,187)$ calls 'substantial selfmanagement power' in relation to the Canadian experience, where redefined relations between native and non-native Canadians have apparently contributed to 'a restructuring of power and responsibility with regard to natural resources'. Significantly, co-management is recognized as a form of crisis resolution produced by long-standing cultural dispositions; an expression and form of reconciliation perhaps. In Australia, there are examples of joint Anglo and Aboriginal management of natural resources (Chester, 2000; Szabo, n.d.). However, because these arrangements unsettle and transform entrenched cultural dispositions that typify many white Australians' relationships with indigenous people they are not the norm (Rintoul, 1993; Gibson, 1999).

It is also salutary to remember that expansionist policies and values were and are resisted from inside the dominant culture. During the $1860 \mathrm{~s}$, for example, there were vigorous debates and campaigns in favour of reduced land clearance in South Australia (Stratford, 1993); these were followed by passionate contests over soil conservation in Australia during the $1930 \mathrm{~s}$, and again during the 1970s and 1980s (Heathcote, 1983; Orchard, 1997). Australia's modern environmental history is also characterized by grim and enduring confrontations 
between conservationists and developers (Bolton, 1992; Dovers, 1994, 2000; McEachern and Doyle, 1998; Gill, 1999), often in relation to ideas about 'wilderness', indigenous land rights and environment more generally. These divisions over the use and management of resources significantly contribute to particular cultural dispositions and values, with Australians having among the highest rates of participation in environmental organizations in the world. Notwithstanding this level of activity, there is limited substantive environmental improvement (Blackmore and Connell, 1997). The depletion of capital assets continues - expressed as soil loss, salinization, degraded water quality, the dislocation of rural communities, lack of urban sustainability or widening economic inequities, for example (Curtis, 1997; Beresford, 2001). Running the risk of listing nostalgic 'what-ifs', we nonetheless think it important to speculate about how different Australians' record of resource development might have been had we better valued - in order to understand-indigenous peoples' cultural dispositions and, as a consequence, their land management techniques. Better to ask what if we were now to deploy the idea of intercultural borderlands to work through cultural differences (Gadgil et al., 1993), and develop and/or refine NRM strategies that account for the full range of capital assets affecting our diverse indigenous and non-indigenous communities.

\section{Migrant stories, diverse communities, cultural translations}

Normatively, race and ethnicity refer to connections of common descent or heredity and the use of specific languages or sub-languages. Race and ethnicity are also entrenched, problematic and historically-specific notions about physical and cultural differentiation among people begun in the early modern period (Merchant, 1989). Too often they have been deployed to invoke hierarchies and to marginalize, as noted above in relation to Australia's colonial and postcolonial history. Moreover, race and ethnicity inform ideas about nation-states as 'imagined communities' that are constantly reproduced through discourses, social practices, and the exercise of power (Anderson, 1991). Indeed the

... nation-state is a crucial locus for the articulation of racist ideologies, because of the extent to which it embodies the idea of 'race' and legitimizes it through the granting or withholding of citizenship, the right to enter and remain within a country, and a host of other entitlements (Jackson and Penrose, 1993, 9).

Among these entitlements is the critical capacity to be represented and to represent oneself in official histories of nationhood (and the use and management of natural resources that these representations and histories imply). Just as indigenous stories have often been silenced, so too have the narratives of non-indigenous ethnic groups whose labours on the land also helped to create the economic prosperity that generations of Anglo-Australians enjoy as a matter of right. Take an example from migrant experiences: the autobiography of a nineteenth century Chinese settler in Australia named Tam Sie who, in 1903, wrote about his experiment with growing rubber and cotton to determine climatic suitability for such crops (Shen, 1999). This is a man who positioned himself in the wider drama of Australian land development. Yet his perspective has only been uncovered through recent postcolonial scholarship, an effect of which is a better understanding of the complex relationship between sense of identity and place. The irony is that despite his perception of having a stake in the development of the land (Shen, 1999), Tam Sie was relegated to the margins of civic life because of the perceived inferiority of his race, and his observations about climate and agriculture, alongside possible insights into the management of natural resources, were lost for almost a century.

In contrast to this colonial legacy of marginalizing non-Anglo (and then non-European) settlers to Australia, contemporary official approaches to multiculturalism are intended to enhance national 'capacity to respond flexibly to the needs of an ethnically mixed population' (DPAC/OMA, 1989, 51, emphasis added; see also ADIMA, 2001). Yet multiculturalism has often been deemed to have failed as a strategy of inclusiveness, and the AngloCeltic continues to occupy the centre through various policies of government and as a function of longstanding xenophobic tendencies in Australia's cultural disposition (Castles, 1997; Davidson, 1997; Perera and Pugliese, 1997; Haggis et al., 1999). Irrespective of the existence of multiculturalism as a national approach, Australians inevitably occupy several communities of identity (McKenzie, 1999; Peisker, 1999) - the intercultural borderlands - such as being simultaneously Vietnamese and Anglo and second generation and Catholic and middle class and professional and female and urban and young. 
An appreciation of this intercultural terrain creates novel opportunities to examine in detail the interrelationships between ethnicity and NRM, which include attitudes and values to the land; differential access to (and valuing of) education and technical information; diverse approaches to land management and farming; or different ideas about participation in NRM programs. Stressing the propensity for migrants to cluster in 'geographic communities, which share origin, language and culture', Cumming and Mathieson (2000, 80) acknowledge that a significant challenge for the national Landcare movement, for example, is to 'meet the needs of this part of the rural population to increase their participation' in NRM (see Curtis and Lockwood, 2000).

This aim demands that knowledge about NRM is accessible and culturally appropriate. In effect, NRM strategists and practitioners need to be familiar with the intercultural borderlands across which different ethnic groups operate; they need to embrace strategies of 'cultural translation' in order to accumulate social and human capital through integrating formal and informal networks and resources which, we posit, will enhance NRM outcomes by improving levels of trust, reciprocity, common ground, shared understanding and diverse solutions. Other forms of cultural translation-in respect of gender and the public and private - are also warranted, and it is to these matters that we now turn.

\section{Gendered subjects, public/ private, cultural change}

Consecutive meetings of the United Nations and related organizations have emphasized the different roles played by women and men in the use, management and reproduction of biophysical and social resources (WCED, 1987; United Nations, 1992; Moser, 1993), as well as the ongoing disadvantages that women, in particular, face in land management and ownership and access to resources. These challenges arise because complex power relations inhere around gender issues, and hinge to others - such as colonialism and neo-colonialism (Gandhi, 1998; Kenyangi, 2000).

In Australia, preparations for the United Nations Conference on Environment and Development in Rio de Janeiro in 1992 included consultations with over 3000 women nation-wide through 1991 (Brown and Broom, 1992; NWCC, 1992a, b). Women were concerned about environmental pollution, health and well-being, waste minimization and conservation; they stressed the importance of education and training provided by them to others, and particularly to children in the home; and they emphasized their capacity to take direct action, negotiate and lobby for environmental change. However, women's excessive burdens in modern Australian society were seen as a serious matter; they still enjoy only 60-70 percent of the male wage, and still shoulder most household work, whether in paid employment or not (ABS, 1998; Bittman, 1991). Women were also the mainstays of many day-to-day environmental actions imperative to better NRM, but even now that work remains undervalued in national statistics and funding strategies, and in the status accorded to women's personal and professional activities, a trend paralleled elsewhere (Sudman, 1998). All the foregoing suggests that women bear a disproportionate amount of environmental and other care work; women's efforts are undervalued and they make do with limited resources and support.

More recently, Elix and Lambert (2000) have found that women's contribution to real farm income is around 48 percent of total income while they remain less than $20 \%$ of the population making decisions in or about the sector (see also Rickson and Daniels, 1999). Moreover, married women in parts of Australia still have limited rights in relation to leasehold land; their husbands (rather than the couple) being the recognized lessees. Again, the issue of under-representation in formal arenas of power and long outdated ideas of women's place are pronounced in these findings. Nevertheless, rural women are important business planners and strategists; yet they face barriers to meaningful involvement and effective leadership roles. Among these are organizational cultures typified by sexist attitudes; family-unfriendly workplaces; limited mechanisms to build self-worth and to have worth recognized by others; the absence of mentoring and role models; particular notions of what constitutes experience in the workplace, leading to skewed implementation of the merit principle; and lack of access to training. In response, Elix and Lambert (2000, 137) suggest numerous strategies to overcome such barriers to women's leadership aspirations and activities that involve 'creating value, rather than maximising profits, recognising people as a valuable resource, valuing teamwork in an inclusive management style and seeing economics and ecology as interconnected'.

Similarly, Liepins (1998) lauds the achievements that have been made in Australian women's agricultural activism over the decade. Liepins insists on the need to better understand those agricultural 
policies that structure opportunities for women in ways that break the counter-productive dichotomy between the personal-private and societal-public (see Davis and Nadel-Klein, 1992). Now commonplace in feminist scholarship and in theories of difference, this strategy should be more rigorously applied in research and practice to enhance policy responses to men's and women's changing roles in various sectors, farming among them (Bryant, 1999). In short, more opportunities for women's full involvement are needed to strengthen their sense of agency and social capacity in finding workable solutions to collective problems such as NRM. In this context, Lappe and Du Bois (1997) argue for extending public life and democratic participation from the formal political sphere to all the public roles that individuals have (whether in employment, education, voluntarism or consumption) to widen the field of common problem-solving (see also Martin and Ritchie, 1999).

Bokemeier (1997) also calls for a break with the public-private dichotomy in her analysis of the central importance of rural families and households. In making a strong connection between research practices in rural sociology and the reproduction of inappropriate and discriminating attitudes and values in the academy and agricultural sectors, Bokemeier's (1997, 3) strategy is to reconfigure both for emancipatory outcomes because families and households are 'the critical and strategic social organization through which individuals shape and adapt to social transformations'. She impresses the need to recognize the reciprocal and interdependent nature of families and households and so-called spheres of public and private activity; it is often in the borderlands between the private and public, in informal exchanges and relations of reciprocity, that social and cultural capital (among which NRM must be included) accumulate and are distributed in rural communities. Given the decline of Australia's rural population numbers, the ageing of that population, and the effects of high morbidity levels, these borderlands are critical places in which to nurture community and the civic practices that attend it, involvement in NRM among them. We examine such issues next.

\section{Population dynamics, generational opportunities, health matters}

Australia's population has been concentrated in urban areas around the coastal fringes because of factors such as climate, distance and economy (Waitt et al., 2000, 298). Despite intermittent attempts by state and federal governments to encourage urbanto-rural migration, there has been a gradual decline in the proportion of the population in rural areas (Champion, 1989; Hugo, 1994; ABS, 2000a; Waitt et al., 2000). Necessarily, these and related demographic trends have implications for NRM, not least in terms of the manifold effects of both urban and rural populations on ecosystems and the range of resources available to governments to aid these populations in NRM. Here, we focus on population growth and characteristics.

Trends in population growth are important for any consideration of NRM. In three series of population projections, the ABS (2000b) suggests that population growth will occur in all jurisdictions except Tasmania and South Australia to 2051. The largest increases in population are anticipated in the Northern Territory (between 84 and 154\%) Queensland (between 76 and 90\%), and Western Australia (between 67 and 74\%), places in which land and water degradation is already severe. How populations are distributed, over what areas, into which ecosystems, using which systems of production, consuming which goods, and living through which particular ethical and moral frameworks will be essential to factor into NRM strategies in such jurisdictions.

Individual and local community population characteristics can also directly and indirectly drive or impede NRM; stage in the lifecycle, for example, impinges on various capital assets such as education, health and well-being, and economy (employment, housing, and the provision of goods and services). Ageing is, and will continue to be, a major concern over the next five decades. Nationally, the median age in 1998 was 34.6, and this is anticipated to rise to around 40-41 in 2021 and to between 43 and 46 in 2051. Furthermore, the proportion of the population aged over 65 years is expected to increase significantly, from $12 \%$ of the total population in 1998 to around $25 \%$ of the total in 2051 (Quandt et al., 1999; Quine, 1999; ABS, 2000b). Youth and aged dependency ratios have significant implications for the tax base, the need for particular goods and services, and the amount of time and energy that people can give to building social capital through involvement in NRM and other environmental actions (Selman, 2001). In relation to rural and regional communities, where the out-migration of young people is a pressing and persistent issue, Larkin and Newman (1997) suggest that a range of benefits may accrue from more frequent interactions between the elderly and the young, and 
from the development and refinement of service providers' and professionals' skills in bringing age groups together. This suggestion has considerable merit in relation to intergenerational mentoring (Rogers and Taylor, 1997), a process which widens and deepens the common grounds between the ages. Indeed its worth is emphasized in the literature on social capital in which generalized trust, reciprocity, and diversity in groups, associations and communities are seen as critical to sustainability (Putnam et al., 1993; Flora, et al., 1997; Stolle and Rochon, 1998; Adler and Kwon, 1999; Falk and Kilpatrick, 2000; C. B. Flora, 2000; J. L. Flora, 2000).

Nonetheless, ideas about intergenerational networks have largely failed to stress the importance of social capital as a mechanism for what Giddens (1994) refers to as the intergenerational flow of wisdom and, we emphasize, a wisdom specifically about the environment. This flow is critical for tracing changes in perceptions, and for understanding both our place in nature and the practices we have adopted to manage the environment. Given that intergenerational equity is a foundational principle of sustainability, it seems vital to foster better long-term communication among the generations, and NRM provides an important vehicle by which to achieve this, promoting the accumulation of human, social and natural capital assets through shared activities in Landcare, Rivercare or community streetscape projects.

Finally, in their discussion on intergenerational commonalities, Larkin and Newman (1997) also refer to issues of health and well-being (see also Gething, 1997; Glendenning, 1998; Brown et al., 1999; Veitch et al., 1999; Malcolm, 2000). The status of any population's health and well-being affects the security of its capital assets. In very different ways, the deleterious effects of ageing, youth suicide, exposure to hazardous chemicals, the social and physical effects of disability, cardiovascular disease and cancer, mental health problems among men and women, and domestic violence continue to affect Australians' quality of life (Connell, 1995; Bramston et al., 2000; Wainer and Chesters, 2000), and the capacity to participate in personal and civic life, particularly in rural areas. An effect of such morbidity on rural communities is to deplete financial and other assets that could be employed for the repair or restoration of rural land and so improve its productivity. Such restoration is particularly pressing in the Australian context where widespread salinity problems substantively impact on the productivity of agricultural land; responses to such challenges, which must necessarily be of a collective kind, are themselves dependent on the generation of social capital.

\section{Conclusion}

We began this critical review with the assertion that NRM policies and practices tend to under-value or under-estimate the central importance of the sociocultural. We suggest that NRM policy and practice constitute land users as rational individuals rather than as complex identities in complex associations whose actions are framed by both formal and informal, implicit and explicit, socio-cultural practices. As a result, much NRM policy fails to be implemented (or implemented well) because it does not account for everyday life practices, values and attitudes (Gunderson et al., 1995). This critique attends our primary claim and concern that NRM policy has been overly reductive and inequitable; and could be more effective and efficient if it focused on the intercultural borderlands and our full range of capital assets, and mastered divergent and accessible methods of delivery. In responding to this concern, we have used the capital assets model and the idea of intercultural borderlands as conceptual tools by which to better understand the sociocultural dimensions of NRM with particular reference to the Australian case.

What is to be concluded from this work? The capital assets model could assist integration across disciplines, cognitive capacities, policy arenas and fields of practice for more effective, efficient and equitable NRM. To generate desirable NRM outcomes implies that all stocks of assets are being accumulated and, conversely, when there are unacceptable or unsustainable levels of land and water degradation not only are natural assets being depleted but other social, human, and financial assets are also threatened - either in being diverted for remediation or as indirect losses to quality of life. However, conscious and deliberate investments in landscape health (natural capital), rather than its unwitting depreciation, are essential to the accumulation of other capital assets including wellbeing. On the other hand, investments in human capital - education and training, health, and nutrition, for example; social capital - trust building and community cohesion, for example; and access to finance are critical to maintain the resource base.

We also envisage a number of positive influences on NRM with attention to the intercultural borderlands, including more diverse and better quality information, and better adaptive capacities to 
address the complexities of NRM issues. Imagine if our legacy had not been constrained by deeply held cultural investments in private property systems, difficult to modify without major social and economic disruption; something understood by Geisler (1999) in his elaboration on culture and inferred by Machlis et al. (1997) in their representations of the human ecosystem, referred to in our introductory comments. Imagine if the dominant culture had been open to the values and possible benefits of other, more communal resource allocation and management traditions. Imagine if the population had been encouraged to develop property institutions alert to the collective goods dimensions (and therefore collective rights) of private property entitlements (Davidson, 1999). Certainly, we speculate that a greater variety of land ethics and property institutions would have provided Australians with greater flexibility in adapting to contemporary global imperatives.

It is our contention that NRM policy and practice needs to better appreciate and explicitly account for everyday values, attitudes and social practices, social norms and cultural dispositions, and how these frame the challenges of sustainability. If, as Geisler (1999) suggests, the socio-cultural bounds the land, makes place out of space, marks the corners and edges of place, defines that which is sacred or to be sacrificed, and decides the ethics and aesthetics of the land, then it must be central to how we meet the challenge of engendering effective, efficient and equitable natural resource management.

\section{References}

Adler, P. S. and Kwon, S.-K. (2000). Social capital: the good, the bad and the ugly. In Knowledge and Social Capital: Foundations and Applications (E. Lesser, ed.). London: Butterworth-Heinemann Ltd.

Anderson, B. (1991). Imagined Communities: Reflections on the Origin and Spread of Nationalism, 2nd edition. London: Verso.

ABS (Australian Bureau of Statistics) (1998). How Australians Use Their Time. Canberra: ABS. http:// www.abs.gov.au/ausstats/abs@.nsf/0/DE84427EFEB3834BCA2568A9001393BD? Open, Cat. No. 4153.0, accessed July 2001.

ABS (Australian Bureau of Statistics) (2000a). http:// www.abs.gov.au/websitedbs/c311215.NSF/Australia+ Now+-+A+Statistical+Profile/, accessed May 2000.

ABS (Australian Bureau of Statistics) (2000b). www.abs. gov.au/Ausstats, accessed June 2000

ADIMA (Australian Department of Immigration and Multicultural Affairs) (2001). Australian Multiculturalism, http://www.immi.gov.au/multicultural/ agenda1.htm, accessed July 2001.
Baker, R. (1999). Land is life: a cultural geography of Australian contact history. In Australian Cultural Geographies (E. Stratford, ed.), pp. 25-47. Melbourne: Oxford University Press.

Beever, H. (1993). Stable catchments the solution: but is it achievable? National conference on land management for dryland salinity control, La Trobe University, Bendigo, 28 September-1 October.

Beresford, Q. (2001). An intractable policy problem? Dealing with the Salinity Crisis, Eenvironmental Policy and Law 31, 173-178.

Bittman, M. (1991). Juggling time: how Australian families use time. Canberra: Office of the Status of Women, Department of Prime Minister and Cabinet.

Blackmore, D. and Connell, D. (1997). Are rural land practices in the Murray Darling basin a threat to the environment? Australian Journal of Soil Research 35, 1037-1047.

Bolton, G. (1992). Spoils and Spoilers: How Australians Have Shaped Their Environment. Sydney: Allen and Unwin.

Bokemeier, J. L. (1997). Rediscovering families and households: restructuring rural society and rural sociology. Rural Sociology 62, 1-20.

Bramston, P., Rogers-Clark, C., Hegney, D. and Bishop, J. (2000). Gender roles and geographic location as predictors of emotional distress in Australian women. Australian Journal of Rural Health 8, 154-160.

Brown, V. A. (1997). Our core business is the future: working towards local agenda 21. In Managing for Local Sustainability: Policy, Problem-Solving, Practice, and Place (V. A. Brown, ed.). Canberra: Commonwealth Department of the Environment, Sport \& Territories.

Brown, V. A. and Broom, D. H. (1992). Australian women's agenda for environmental action: engendering sustainable development. National women's consultative committee occasional paper No. 1. Canberra: Commonwealth of Australia.

Brown, W. J., Young, A. F. and Byles, J. E. (1999). Tyranny of distance? The health of mid-age women living in five geographical areas of Australia. Australian Journal of Rural Health 7, 148-154.

Bryant, L. (1999). The detraditionalization of occupational identities in farming in South Australia. Sociologia Ruralis 39, 236-261.

Butt, P. and Eagleson, R. (1998). Mabo, Wik and Native Title. 3rd edition. Sydney: The Federation Press.

Castles, S. (1997). Multicultural citizenship: a response to the dilemma of globalisation and national identity? Journal of Intercultural Studies 18, 5-23.

Champion, A. G. (ed.) (1989). Counterurbanisation: The Changing Pace and Nature of Population Deconcentration. London: Edward Arnold.

Chester, J. (2000). Partnerships and projects developing interagency actions toward reconciliation. Changing landscapes, shaping futures. International landcare 2000 conference, Melbourne, 75-76.

Clark, T. (1993). Creating and using knowledge for species and ecosystem conservation: science, organisations and policy. Perspectives in Biology and Medicine 36, 497-525.

Connell, R. W. (1995). Masculinities. Sydney: Allen and Unwin.

Cumming, B. and Mathieson, L. (2000). Enhancing diversity of participation in landcare. Changing landscapes, shaping futures. International Landcare 2000 Conference, Melbourne, 80-84. 
Curtis. A. (1997). Landcare, stewardship and biodiversity conservation. In Frontiers in Ecology: Building the links (N. I. Klomp and I. Lunt, eds), pp. 143-153. Oxford: Elsevier Science.

Curtis, A. and Lockwood, M. (2000). Lessons for an international audience from the Australian experience with landcare. Changing landscapes, shaping futures. International Landcare 2000 Conference, Melbourne, Victoria, 84-89.

Davidson, A. (1997). Multiculturalism and citizenship: silencing the migrant voice. Journal of Intercultural Studies 18, 77-93.

Davidson, J. L. (1999). In Search of the Ecologically Responsible Society: Sustainability as Ecopraxis. Unpublished PhD Thesis, University of Tasmania, Hobart.

Davidson, J. (forthcoming). Citizenship and Sustainability in Dependent Communities: the Case of the Huon Valley Region in Southern Tasmania. Local Environment.

Davis, D. L. and Nadel-Klein, J. (1992). Gender, culture and the sea: contemporary theoretical approaches. Society and Natural Resources 5, 135-147.

Dietzel, J. (1997). The Healthy Rivers Project in Tasmania. ECOS, 4, n.p.

DPAC/OMA (Department of Prime Minister and Cabinet/Office of Multicultural Affairs) (1989). National Agenda for a Multicultural Australia. Canberra: Australian Government Printing Service.

Dovers, S. (1994). Australian Environmental History. Melbourne: Oxford University Press.

Dovers, S. and Mobbs, C. (1999). Social, economic, legal, policy and institutional R\&D for natural resources management. Country Matters Conference: National Conference on the Role of the Social Sciences in Developing Policies and Programs for Australia's Rural Industries, May 20-21.

Drew, P. (1994). The Coast Dwellers: A Radical Reappraisal of Australian Identity. Melbourne: Penguin.

Elix, J. and Lambert, J. (2000). Missed opportunities: harnessing the potential of women in Australian agriculture. Changing landscapes, shaping futures. International Landcare 2000 Conference, Melbourne, 135-140.

Falk, I. and Kilpatrick, S. (2000). What is social capital? A study of interaction in a rural community. Sociologia Ruralis 40, 87-110.

Farina, A. (2000). The cultural landscape as a model for the integration of ecology and economics. Bioscience 50, 313-320.

Fiske, J., Hodge R. and Turner, G. (1987). The Myths of Oz: Reading Australian Popular Culture. Sydney: Allen and Unwin.

Flora, C. B. (2000). Social Capital and Sustainability: Agriculture and Communities in the Great Plains and Corn Belt, Social Capital Talk. www.worldbank.org/ poverty/scapital/sctalk, accessed April, May, June 2000.

Flora, J. L. (2000). Social Capital and Communities of Place, Social Capital Talk. www.worldbank.org/ poverty/scapital/sctalk, accessed April, May, June 2000.

Flora, J. L., Sharp, J., Flora, C. B. and Newlon, B. (1997). Entrepreneurial social infrastructure and locally initiated economic development in the nonmetropolitan United States. The Sociological Quarterly 38, 623-646.

Gadgil, M., Berkes, F. and Folke, C. (1993). Indigenous knowledge for biodiversity conservation. Ambio 22, 151-156.
Gandhi, L. (1998). Postcolonial Theory: A Critical Introduction. Sydney: Allen and Unwin.

Geisler, C. C. (1999). Estates of mind: culture's many paths to land. Society and Natural Resources 13, 51-60.

Gething, L. (1997). Sources of double disadvantage for people living in remote and rural areas of New South Wales, Australia. Disability and Society 12, 513-531.

Gibson, C. (1999). Cartographies of the colonial/capitalist state: a geopolitics of indigenous self-determination in Australia. Antipode 31, 45-79.

Giddens, A. (1994). Beyond Left and Right: the Future of Radical Politics. Cambridge: Polity Press.

Gill, N. (1999). The ambiguities of wilderness. In Australian Cultural Geographies (E. Stratford, ed.), pp. 48-67. Melbourne: Oxford University Press.

Glendenning, A. (1998). Family life, health and lifestyles in rural areas: the role of self-esteem. Health Education No. 2, March, 59-68.

Gundersen, L. H., Holling, C. S. and Light, S. S. (eds) (1995). Barriers and Bridges to the Renewal of Ecosystems and Institutions. New York: University of Columbia Press.

Haggis, J., Schech, S. and Fitzgerald, G. (1999). Narrating lives, narrating whiteness: a research note. Journal of Australian Studies March, 168ff.

Hart, M. (2002). What is Sustainability Anyway? Sustainable Measures, http://www.sustainablemeasures.com, accessed March 2002.

Heathcote, R. L. (1983). The Arid Lands: Their Use and Abuse. New York: Longman.

Hills, E. R. (1991). The imaginary life: landscape and culture in Australia. Journal of Australian Studies 29, 12-27.

Hugo, G. J. (1994). The turnaround in Australia: some first observations for the 1991 census. The Australian Geographer 25, 1-17.

Huon Valley Council (1999). Huon Catchment Healthy Rivers Project. Catchment Management Plan. Huonville: HVC.

Jackson, P. and Penrose, J. (eds) (1993). Constructions of Race, Place and Nation. London: University College London Press.

Kenyangi, G. (2000). Women landcare and sustainable development. Changing landscapes, shaping futures. International Landcare 2000 Conference, Melbourne, 130-132.

Labinger, J. (1995). Science as culture: a view from the Petri dish. Social Studies of Science 25, 285-306.

LWRRDC (Land and Water Resources Research and Development Corporation) (2000). Social and Institutional Research Program 1999-2004 Plan. Canberra: LWRRDC.

Lappe, F. M. and Du Bois, P. M. (1997). Building social capital without looking backward. National Civic Review 82, 119-129.

Larkin, E. and Newman, S. (1997). Intergenerational studies: a multi-disciplinary field. Journal of Gerontological Social Work 28, 5-16.

Liepins, R. (1998). Fields of action: Australian women's agricultural activism in the 1990s. Rural Sociology 63, 128-156.

Machlis, G. E., Force, J. E. and Burch, W. R. (1997). The human ecosystem Part I: the human ecosystem as an organizing concept in ecosystem management. Society and Natural Resources 10, 347-367. 
Malcolm, H. (2000). A primary mental health-care model for rural Australia: Outcomes for doctors and the community. Australian Journal of Rural Health 8, 167-172.

Martin, P. and Ritchie, H. (1999). Logics of participation: rural environmental governance under neoliberalism in Australia. Environmental Politics 8, 117-135.

McEachern, D. and Doyle, T. (1998). Environment and Politics. London: Routledge.

McKenzie, P. (1999). Swimmling in and out of focus: second contact, Vietnamese migrant others and Australian selves. Australian Journal of Anthropology 10, $271 \mathrm{ff}$.

Merchant, C. (1989). The Death of Nature: Women, Ecology and the Scientific Revolution. New York: Harper and Row.

Mitchell, W. J. T. (1994). Imperial Landscape. In Landscape and Power (W. J. T. Mitchell, ed.), pp. 5-34. Chicago and London: The University of Chicago Press.

Moser, C. (1993). Gender Planning and Development: Theory, Practice and Training. London and New York: Routledge.

NWCC (National Women's Consultative Committee) (1992a). A Question of Balance: Australian Women's Priorities for Environmental Action. Canberra: Commonwealth of Australia.

NWCC (National Women's Consultative Committee) (1992b). What on Earth Can a Woman Do? Results of Consultations on Women and Environment. Summary Paper. Canberra: Commonwealth of Australia.

Notzke, C. (1995). A new perspective in aboriginal natural resource management: co-management. Geoforum 26, 187-209.

Orchard, L. (1997). Australian agricultural historiography: a survey. Agricultural History 71, 479-491.

Peisker, V. C. (1999). Two waves of Croatian migrants in Western Australia: class and national identity. Australian Journal of Social Issues 34, 353ff.

Perera, S. and Pugliese, J. (1997). 'Racial suicide': the re-licensing of racism in Australia. Race and Class 39, $1-19$.

Perreault, T. A., Bebbington, A. J. and Carroll, T. F. (1998). Indigenous irrigation organizations and the formation of social capital in Northern Highland Ecuador. Yearbook: Conference of Latin Americanist Geographers 24, 1-15.

Powell, J. M. (1978). Mirrors of the New World: Images and Image-Makers in the Settlement Process. Canberra: Australian National University Press.

Pretty, J. (2000). Changing Agricultural Practices and their Impact on Biodiversity. University of Cambridge Committee for Interdisciplinary Environmental Studies, Presented $16^{\text {th }}$ March. http://www-cies.geog.cam. ac.uk/www-cies/PubLect/pretty.html, accessed March 2002.

Pretty, J. and Frank, B. R. (2000). Participation and social capital formation in natural resource management: achievements and lessons. Changing landscapes, shaping futures. International Landcare Conference 2000, Melbourne, 178-188.

Pretty, J. and Hine, R. (2000). The promising spread of sustainable agriculture in Asia. Natural Resources Forum 24, 107-121.

Pretty, J. and Ward, H. (2001). Social capital and the environment. World Development 29, 209-227.
Putnam, R., Leonardi, R. and Raffaela, Y. N. (1993). Making Democracy Work: Civic Traditions in Modern Italy. Princeton: Princeton University Press.

Quandt, S. A., McDonald, J., Bell, R. A. and Arcury, T. A. (1999). Aging research in multi-ethnic rural communities: gaining entrée through community involvement. Journal of Cross-Cultural Gerontology 14, 113-130.

Quine, S. (1999). Health concerns and expectations of anglo and ethnic older Australians: a comparative approach. Journal of Cross-Cultural Gerontology 14, 97-111.

Rickson, S. T. and Daniels, P. L. (1999). Rural women and decision making: women's role in resource management during rural restructuring. Rural Sociology 64, $234 \mathrm{ff}$.

Riddett, L. (1995). Think again: communities which lose their memory: the construction of history in settler societies. Journal of Australian Studies 44, 38-47.

Rintoul, S. (1993). The Wailing. A National Black Oral History. Sydney: Heinemann Australia.

Rogers, A. M. and Taylor, A. S. (1997). Intergenerational mentoring: a viable strategy for meeting the needs of vulnerable youth. Journal of Gerontological Social Work 28, 125-140.

Rose, D. B. (1996). Wilderness and the Wild, in Nourishing Terrains: Australian Aboriginal Views of Landscape and Wilderness. Chapter 2. Canberra: Australian Heritage Commission.

Ryan, S. (1996). The Cartographic Eye: How Explorers Saw Australia. Cambridge: Cambridge University Press.

Sandercock, L. (1998). Towards Cosmopolis: Planning for Multicultural Cities. Chichester: John Wiley and Sons.

Schaffer, Kay (1988). Women and the Bush: Forces of Desire in the Australian Cultural Tradition. Melbourne: Cambridge University Press.

Selman, P. (2001). Social capital, sustainability and environmental planning. Planning Theory and Practice 2, 13-30.

Shen Yuan-fang (1999). Pioneers or sojourners: selfrepresentations of Chinese immigrants. Journal of Australian Studies June, 47ff.

Stolle, D. and Rochon, T. R. (1998). Are all Associations alike? American Behavioral Scientist 42, 47-66.

Stratford, E, (1993). Ideology, environment and legislation: South Australian attitudes to vegetation. Australian Geographical Studies 31, 14-25.

Stratford, E. (1999). Introduction. In Australian Cultural Geographies (E. Stratford, ed.), pp. 1-10. Meridian Series in Geography. Melbourne: Oxford University Press.

Stratford, E. (2000). Gender, place and travel: the case of Elsie Birks, South Australian Pioneer. Journal of Australian Studies: Vision Splendid 66, 116-128.

Stratford, E. and Davidson, J. (2001). Strategic Issues, Options and Trends for the Huon Valley Municipality. The SD Group of Consultants, Hobart.

Stratford, E. Mazur, N. Lunney, D. and Bennett, D. (2000). Managing the Koala problem: interdisciplinary perspectives. Conservation Biology 14, 610-618.

Sudman, R. S. (1998). Contributions of women in the field of water resources. Water Resources Development 14, 473-479.

Szabo, S. (no date). Aboriginal and Torres Strait Islander Involvement in Natural Resource Management in Australia. NPA Bulletin, 17-18. 
United Nations (1992). Agenda 21. In The Earth Summit: The United Nations Conference on Environment and Development (UNCED) (S. P. Johnson, ed.) (1993). London: Graham and Trotman/Martinus Nijhoff.

Veitch, C., Harte, J., Hays, R., Pashen, D. and Clark, S. (1999). Community participation in the recruitment and retention of rural doctors: methodological and logistical considerations. Australian Journal Rural Health 7, 206-211.
Wainer, J. and Chesters, J. (2000). Rural mental health: neither romanticism nor despair. Australian Journal of Rural Health 8, 141-147.

Waitt, G., McGuirk, P., Dunn, K., Hartig, K. and Burnley, I. (2000). Introducing Human Geography: Globalisation, Difference and Inequality. Sydney: Longman.

WCED (World Commission on Environment and Development) (1987). Our Common Future. Oxford: Oxford University Press. 